\title{
Biomass yield of maize fodder at different plant density, its preference and digestibility by Sokoto Gudali heifers
}

${ }^{1}$ Adegbite, J. A., ${ }^{2}$ Nwamo, A. C and ${ }^{1}$ Olorunnisomo, O. A.

${ }^{I}$ Department of Animal Science, University of Ibadan, Oyo State, Nigeria

${ }^{2}$ National Veterinary Research Institute, Vom. Plateau state. Nigeria.

Corresponding author: adurajoe@yahoo.com; +2347032743753

Abstract

This study was conducted to investigate the effect of plant density on biomass yield of maize fodder, its acceptability and digestibility by Sokoto Gudali heifers. Treatments P1, P2, P3 and P4 correspond to different plant densities of 53,333, 106,666, 210,526 and 421,072 plants/ha, respectively. Each treatment was replicated three times on $4 \mathrm{~m} \times 10 \mathrm{~m}$ plots and fertilizer was applied as $100 \mathrm{~kg} \mathrm{~N} / \mathrm{ha}$. Fodder was harvested at 6weeks of age (42 days after planting) and weighed to determine the biomass yield. Samples were also taken for chemical analysis. Harvested fodder were fed to Sokoto Gudali heifers to determine its preference and digestibility. Biomass yield increased significantly $(P<0.05)$ within plant population with $P 4$ (3.55 tons/ha) having the highest yield and P1 (1.61 tons/ha) having the least. Dry matter (DM, 23.64-27.22\%) and crude protein (CP, 19.75-27.50\%) of fodder increased as plant population increased while fibre components ( $A D F, N D F$ AND ADL) decreased. In this study, an increase in plant density produced more forage yield of very good quality with high dry Matter digestibility and no variation $(P>0.05)$ in the preference by the animal.

Keywords; Plant Density, Maize Fodder, Preference, Digestibility, Sokoto Gudali Heifers.

\section{Introduction}

Green fodder is the natural diet for livestock. Its production to meet the current demand has become a great challenge among livestock farmers. Due to many reasons, green fodder production has been facing serious crisis and consequently, livestock productivity. About 97 percent of Nigeria's ruminant animals are dependent on forage and fodder crops for their productivity. Due to increasing intensive system of rearing livestock, the need for green fodder is enormous. As the gap between the demand and supply of the green fodder for livestock is becoming wider, researchers and farmers are in search for an alternative fodder or fodder production method that would restore fodder and livestock production. Maize green forage, particularly when it contains the stalks, leaves and ears, is an energy feed for ruminant livestock and its use for animal feeding is becoming very important especially on small scale mixed farms in the tropics. In areas where conditions are harsh and forage is scarce, maize green forage is a valuable source of fodder for smallholders (Methu et al., 2006). This type of forage contributes up to $24 \%$ of the total cattle feed thus making maize production for grain and fodder equally important. Maize forage is nutritious to ruminants and contains appreciable quantity of protein, fat, vitamins and carbohydrates. In the tropics, while grass forages must be harvested almost monthly, maize forage matures within three months, is harvested only once, and does not require much labour and machinery costs (Brewbaker, 2003). Maize forage has been reported to increase productivity of ruminant animals, thereby, increasing their potential contribution to man's supply of meat, in a very cost effective manner (Halima and Chauhan, 2003). For decades, maize growers have worked for continuous improvement and greater efficiency (Singh et al., 2002) and increasing the plant density of maize forage 
from 40,000 to 100,000 plants/ha increased the whole plant yield (Cox, 1996). When inter-row spacing is maintained at $76 \mathrm{~cm}$ and intra-row spacing is reduced, plant population increased from 45,000 to 105,000 plants/ha and biomass yield increased by 10 to $26 \%$ (Cox et al., 1998). Therefore, this study is to investigate the relationship between maize forage yield and plant density needed for sustainable yield and quality of forage.

\section{Materials and method \\ Experimental location}

The experiment was carried out at the Dairy Unit of the Teaching and Research Farm University of Ibadan, Ibadan, Nigeria. The University falls within longitude $3^{\circ} 45^{\prime} \mathrm{E}$ and latitudes $7^{\circ} 27^{\prime} \mathrm{N}$ with mean temperature range of $25-29^{\circ} \mathrm{C}$, average annual rainfall of about $1250 \mathrm{~mm}$ and average mean relative humidity of about $72 \%$.

\section{Experimental animals}

12 Sokoto Gudali heifers of about 18 months of age were used for the animal trials. The heifers were reared under an intensive management system. Prior to the commencement of the experiment, the animals were pre-treated against endo and ecto parasites using ivemectin injection. Dosage was based on $1 \mathrm{ml}$ per $10 \mathrm{~kg}$ / body weight of individual animal.

\section{Agronomic practices}

\section{Planting material}

A commercial hybrid variety of maize seed called SUWAN 1 DMR-LSRY (Resistance variety to downy mildew and Streak) was used in this study. The seeds were collected from National Agricultural Seed Council (NASC) Ibadan, Oyo State.

\section{Experimental field management and land preparation}

The experimental land was prepared by a tractor and ploughed using a disc plough, harrowed and levelled. The seeds were sown at depth of 4- $5 \mathrm{~cm}$ for $2-3$ seeds per hole to ensure adequate emergence and were thinned 7 days after emergence to maintain the intended number of plants per hole and intra-row spacing between plants to attain the specified plant populations.

Experiment layout, plot size and plant density

The experimental land was divided into individual plot size of $4 \mathrm{~m} \times 10 \mathrm{~m}$ with three replications each arranged along the contour of the field and a space of $1 \mathrm{~m}$ was maintained between the plots to prevent movement of nutrients across the plots. A spacing of $25 \mathrm{~cm}$ intra- row and $75 \mathrm{~cm}$ interrow for treatments A and B and $25 \mathrm{~cm}$ intrarow and $19 \mathrm{~cm}$ inter- row for treatments $\mathrm{C}$ and D was adopted throughout with 1-2 plants per stand to attain the specified plant populations giving rise to a population of $53,333 \mathrm{plants} / \mathrm{ha}, 106,666 \mathrm{plants} / \mathrm{ha}$, 210,526plants/ha and 421,072plants/ha, respectively.

\section{Fertilizer application and weeding}

Fertilizer was applied as $100 \mathrm{kgN} /$ ha of urea by band application method. Weeding was done as needed manually with hoe, insecticide was applied to prevent maize insect infestation. Other crop management practices were carried out uniformly for each plot as per the recommendation at the appropriate time (EARO, 2004).

\section{Harvesting}

Maize fodder were harvested from each plot at day forty-two (42) by cutting the maize plant at $15 \mathrm{~cm}$ above the ground and weighed using a spring balance and cumulative yield for each treatment was determined.

\section{Treatment and replication}

The treatments consisted of two inter-row spacing (75 and $19 \mathrm{~cm}$ ) and two levels of seeding per hole ( 1 and 2 seed per hole) (Table 1). Intra-row spacing of $25 \mathrm{~cm}$ was used. Each treatment was replicated three times. The experimental seeds were sown in each hole and later thinned according to the treatment. 
Table 1: Experimental treatment of maize fodder at different plant densities

\begin{tabular}{ccccc}
\hline Treatments & $\begin{array}{l}\text { Inter-row spacing } \\
(\mathrm{cm})\end{array}$ & $\begin{array}{l}\text { Intra-row spacing } \\
(\mathrm{cm})\end{array}$ & $\begin{array}{l}\text { Number of } \\
\text { plants per hole }\end{array}$ & $\begin{array}{l}\text { Plant density } \\
\text { (plants/ha) }\end{array}$ \\
\hline P1 & 75 & 25 & 1 & 53,333 \\
P2 & 75 & 25 & 2 & 106,666 \\
P3 & 19 & 25 & 1 & 210,526 \\
P4 & 19 & 25 & 2 & 421,072 \\
\hline
\end{tabular}

Collection and preparation of experimental diet

The maize fodder used in this experiment were collected from plots in the agronomic studies. Fresh maize fodder was collected from the plots of each treatment harvested at six (6) weeks at about $15 \mathrm{~cm}$ from the ground and chopped into small pieces of about $3 \mathrm{~cm}$ length using mechanical chopper. The fodder was served daily at $10 \%$ body weight of the heifers from each treatment. Fresh water was offered daily on free choice basis.

\section{Experimental measurements} Forage yield

Forage yield from each plot at each harvest was recorded. The total forage yield for each treatment was determined as a summation of yields from the harvest and an average of yields from the three replicates.

\section{Chemical composition of maize fodder}

Sample of each treatment maize fodder were taken from each plots during each harvest and oven dried at $65^{\circ} \mathrm{C}$ to a constant weight, milled and stored in an air tight container for analysis. Dry matter (DM) of both faeces and diet were determined by drying in forced draught oven at $105^{\circ} \mathrm{C}$ until constant weight was attained.

Moisture content $=$

Wet weight-Final weight

$\%$ Moisture content $=$

Wet weight-Final weight $x 100$

Wet weight

$\%$ Dry matter $=$ Final weight $\times 100$

Wet weight

The maize fodder was analysed for Dry Matter (DM), Crude Protein (CP), Acid
Detergent Fibre (ADF), Neutral Detergent Fibre (NDF) and Acid Detergent Lignin (ADL). Proximate analysis was done using the methods of AOAC (2005). Detergent fibre content was determined by the methods of Van Soest et al. (1991).

\section{Preference by Sokoto Gudali heifers}

Eight Sokoto Gudali heifers were housed in an open enclosure to evaluate the free choice intake of different experimental fodders for a period of 10 days. The first 3 days for adaptation and the last 7 days for acceptability trials. Each treatment diet was harvested daily at 6 weeks, chopped to about $3 \mathrm{~cm}$ length using mechanical chopper. In duplicates, $20 \mathrm{~kg}$ of each diet was weighed into eight labelled feeding troughs and the feeding troughs were placed in strategic locations. The animals were allowed to feed for 45 minutes and later moved out of the feeding area. Leftover of each diet was then gathered together, weighed and recorded.

Fodder intake $=$ Total Quantity offered Remnant

Coefficient of preference (COP) was calculated as the ratio of individual intake to the average intake of the four diets (Babayemi et al., 2006). According to Babayemi (2007) fodder was regarded acceptable when COP is greater than 1 .

$\mathrm{COP}=$ Intake of individual fodder Average intake of fodder

When $\mathrm{COP}>1=$ Acceptable $\mathrm{COP}<1=$ Not acceptable

Percentage (\%) Preference was calculated as the ratio of individual intake to total intake of all the treatment diets multiplied by 100 (O1orunnisomo 2011; 
Olorunnisomo and Fayomi, 2012). Ranking was based on $\%$ Preference.

$\%$ Preference $=\underline{\text { Individual intake }} \times 100$

Total Intake

\section{Digestibility of maize fodder}

A total of 12 Sokoto Gudali heifers were used for the digestibility study. The animals were randomly assigned to four (4) treatment diets/plant: P1, P2, P3 and P4. Each treatment had three replicates with one animal per replicate. They were housed in an individual open sided pen with low walls and concrete floor. Maize fodder were harvested at 6weeks and chopped to about $3 \mathrm{~cm}$ length; a known quantity of each treatment diet was fed to the animals for 14days. Fresh water was offered free choice on daily basis. Animals were adapted to experimental diets and individual pen environment during the first seven (7) days while feed leftover and faeces voided were collected, weighed and recorded in the last seven (7) days.

\section{Method of faecal collection}

In-situ faecal collection method which involves collecting faeces as soon as it was voided was used. Faeces were collected for an average of 5- 6 times per animal per day and recorded in the last 7 days. 10\% of faeces voided was taken daily from each animal after thorough mixing, oven dried at $65^{\circ} \mathrm{C}$, milled and kept in an air tight containers for chemical analysis.
Apparent digestibility of the diets was calculated as the difference between nutrient intake and excretion in the faeces, expressed as a percentage of nutrient intake using the following equation:

$\mathrm{D}_{\mathrm{x}}=\underline{(\mathrm{F} 0 \times \mathrm{A} 0)-(\mathrm{F} 1-\mathrm{A} 1)} \times 100$

$$
\text { (F0xA0) }
$$

Where $D_{X}=$ Digestibility coefficient of nutrient

$$
\mathrm{F}_{0}=\text { Feed Intake of individual }
$$

$\operatorname{animal}(\mathrm{kg})$

$$
\begin{aligned}
& \mathrm{A}_{0}=\text { Dry matter in feeds } \\
& \mathrm{F}_{1}=\text { Faecal output of individual }
\end{aligned}
$$

animal $(\mathrm{kg})$

$$
\mathrm{A}_{1}=\text { Dry matter in faeces }
$$

\section{Statistical analysis}

All data obtained were subjected to analysis of variance (ANOVA) and significant means were separated by Duncan's multiple range tests using the procedures of SAS (1999).

\section{Results}

The biomass yield (tons/ha) of maize fodder planted at different densities (P1, P2, P3 and P4) for 42 days growth period is presented in Table 2. There were significant differences $(\mathrm{P}<0.05)$ between $\mathrm{P} 4: \mathrm{P} 3$ and $\mathrm{P} 2: \mathrm{P} 1$ with mean of $4.54: 4.17$ and 2.66:2.30 (tons/ha) respectively. While there were no significant differences $(\mathrm{P}>0.05)$ in the biomass yield of $\mathrm{P} 4>\mathrm{P} 3$ as well as in P2 $>$ P1.

Table 2: Biomass yield (tons/ha) of maize fodder planted at different densities

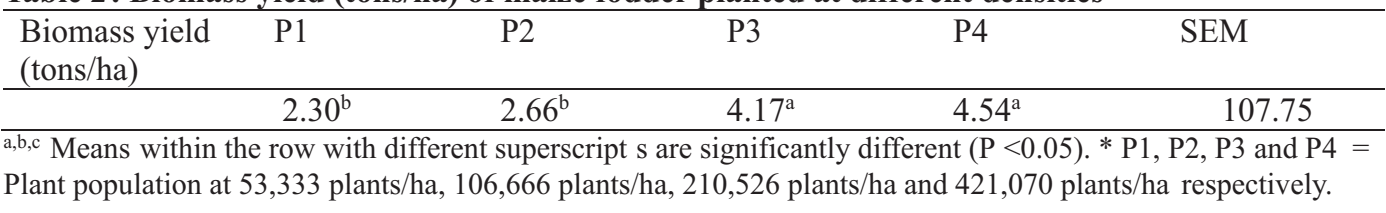

\section{Chemical composition of maize fodder}

The chemical composition of maize fodder at harvested at day 42 is presented in Table 3. The Dry Matter showed that P4 was similar to $\mathrm{P} 3(\mathrm{P}>0.05)$ but significantly different $(\mathrm{P}<0.05)$ from $\mathrm{P} 1$ and $\mathrm{P} 2$. Although P2 and P1 were not significantly different $(\mathrm{P}>0.05)$. There was no significant difference $(\mathrm{P}>0.05)$ in the Crude Protein of $\mathrm{P} 4$ and $\mathrm{P} 3$ but were significantly different $(\mathrm{P}<0.05)$ from the $\mathrm{CP}$ of $\mathrm{P} 2$ and $\mathrm{P} 1$ while there was significant difference $(\mathrm{P}<$ 0.05 ) in the CP of P2 and P1. The Neutral Detergent Fibre showed that P1 was 


\section{Adegbite, Nwamo and Olorunnisomo}

significantly different $(\mathrm{P}<0.05)$ from $\mathrm{P} 2, \mathrm{P} 3$ and P4 though P3 was not significantly different $(\mathrm{P}>0.05)$ from $\mathrm{P} 2$ and $\mathrm{P} 3$. The Acid Detergent Fibre showed that the ADF of $\mathrm{P} 1$ and $\mathrm{P} 2$ was significantly different ( $\mathrm{P}$ $<0.05$ ) from the ADF of P4 but were not significantly different $(\mathrm{P}>0.05)$ from the ADF of P3. Also, there were no significant differences $(\mathrm{P}>0.05)$ between $\mathrm{P} 3$ and $\mathrm{P} 4$. Also the Acid Detergent Lignin of P1 and $\mathrm{P} 2$ was similar $(\mathrm{P}>0.05)$ but significantly different $(\mathrm{P}<0.05)$ from $\mathrm{P} 3$ and $\mathrm{P} 4$.

Table 3: Chemical composition of maize fodder planted at different densities

\begin{tabular}{llllll}
\hline Parameters $(\%)$ & P1 & P2 & P3 & P4 & SEM \\
\hline DM & $23.64^{\mathrm{c}}$ & $25.02^{\mathrm{bc}}$ & $26.46^{\mathrm{ab}}$ & $27.22^{\mathrm{a}}$ & 0.25 \\
CP & $19.75^{\mathrm{c}}$ & $22.55^{\mathrm{b}}$ & $26.40^{\mathrm{a}}$ & $27.50^{\mathrm{a}}$ & 0.25 \\
NDF & $78.10^{\mathrm{a}}$ & $74.70^{\mathrm{b}}$ & $73.75^{\mathrm{bc}}$ & $72.10^{\mathrm{c}}$ & 0.23 \\
ADF & $35.60^{\mathrm{a}}$ & $34.70^{\mathrm{a}}$ & $33.60^{\mathrm{ab}}$ & $32.20^{\mathrm{b}}$ & 0.25 \\
ADL & $18.60^{\mathrm{a}}$ & $18.00^{\mathrm{a}}$ & $15.60^{\mathrm{b}}$ & $14.90^{\mathrm{b}}$ & 0.25 \\
\hline
\end{tabular}

P1, P2, P3 and P4 = Plant population at 53,333 plants/ha, 106,666 plants/ha, 210,526 plants/ha and 421,070 plants/ha respectively; $\mathrm{DM}=$ Dry matter; $\mathrm{CP}=$ Crude protein; $\mathrm{NDF}=$ Neutral Detergent Fibre; $\mathrm{ADF}=$ Acid Detergent Fibre; $\mathrm{ADL}=$ Acid Detergent Lignin.

Table 4: Preference for maize fodder planted at different densities by Sokoto Gudali heifers

\begin{tabular}{llllll}
\hline Parameters & P1 & P2 & P3 & P4 & SEM \\
\hline AVFI $(\mathrm{kg})$ & 15.18 & 14.00 & 12.68 & 13.78 & 0.36 \\
CoP & 1.13 & 0.97 & 0.91 & 1.05 & 0.05 \\
\%Pref. & 26.53 & 24.11 & 22.84 & 26.27 & 1.12 \\
Ranking & $1^{\text {st }}$ & $3^{\text {rd }}$ & $4^{\text {th }}$ & $2^{\text {nd }}$ & - \\
\hline
\end{tabular}

$\overline{a, b, c}$ Means within the row with different superscripts are significantly different $(\mathrm{P}<0.05) .{ }^{*}$ AVFI $=$ Average Feed Intake; $\mathrm{CoP}=$ Coefficient of Preference; \%Pref. = Percentage Preference; P1, P2, P3 and P4= Plant population at 53,333 plants/ha, 106,666 plants/ha, 210,526 plants/ha and 421,070 plants/ha respectively; SEM: Standard Error of Mean.

Preference of Sokoto Gudali heifers for maize fodder planted at different densities at 42 days growth is shown in Table 4 . There were no significant differences $(\mathrm{P}>0.05)$ in all the parameters measured but numerical differences exist. P1 had the highest CoP value of 1.13 which was not significantly different $(\mathrm{P}>0.05)$ from $\mathrm{P} 2, \mathrm{P} 3$ and $\mathrm{P} 4$, and same trend occurred with \% Preference. The ranking of $\%$ Preference was $\mathrm{P} 1>\mathrm{P} 4>\mathrm{P} 3>\mathrm{P} 2$.

Table 5: Dry matter digestibility by Sokoto Gudali heifers fed maize fodder planted at different densities

\begin{tabular}{llllll}
\hline Parameters & P1 & P2 & P3 & P4 & SEM \\
\hline FI (g/day, DM) & $131.24^{\mathrm{d}}$ & $142.75^{\mathrm{c}}$ & $246.34^{\mathrm{b}}$ & $319.43^{\mathrm{a}}$ & 0.26 \\
FO (g/day, DM) & $26.35^{\mathrm{d}}$ & $22.90^{\mathrm{c}}$ & $53.68^{\mathrm{b}}$ & $58.27^{\mathrm{a}}$ & 0.21 \\
DMD (\%) & $80.08^{\mathrm{bc}}$ & $84.30^{\mathrm{a}}$ & $78.30^{\mathrm{c}}$ & $81.59^{\mathrm{b}}$ & 0.35 \\
\hline
\end{tabular}

$\overline{\mathrm{a}, \mathrm{b}, \mathrm{c}}$ Means within the row with different superscripts are significantly different $(\mathrm{P}<0.05)$. $* \mathrm{FI}=$ Feed Intake; FO $=$ Faecal Output; DMD = Dry Matter Digestibility; P1, P2, P3 and P4 = Plant population at 53,333 plants/ha, 106,666 plants/ha, 210,526 plants/ha and 421,070 plants/ha respectively; SEM: Standard Error of Mean.

Table 5 shows the Dry Matter Digestibility (DMD) and Feed Intake (FI) of maize fodder as well as Faecal Output (FO) voided by Sokoto Gudali heifers. It revealed that there were significant differences $(\mathrm{P}<0.05)$ for FI and FO across the treatment. The DMD result in $\mathrm{P} 2$ was significantly different $(\mathrm{P}<0.05)$ from $\mathrm{P} 1, \mathrm{P} 4$ and $\mathrm{P} 3$ while $\mathrm{P} 3$ was significantly different $(\mathrm{P}<$ 0.05 ) from $\mathrm{P} 2$ and $\mathrm{P} 4$. Also there were no 
significant differences $(\mathrm{P}>0.05)$ between $\mathrm{P} 1$ and $\mathrm{P} 3$ as well as $\mathrm{P} 1$ and $\mathrm{P} 4$.

\section{Discussion}

The study of maize fodder planted at different densities recorded an increase in the biomass yield with increase in plant population. According to Ayub et al. (1999) and Norwood (2001), yield component is affected by proper plant density. Mazaheri et al. (2002); Hassanzadeh and Basafa (2006), reported that enhancing plant density increased forage yield significantly. Malik et al. (2007) and Osman et al. (2010) also reported significant improvement in fodder yield at higher plant population. The authors opined that the increase in biomass yield at higher plant population may be due to more number of plants per unit area, higher plant height and higher leaf area index. Similar results have also been reported by Amanullah et al. (2009). This present study revealed that the biomass yield increased significantly with increase in plant population up to 421,072 plants/ha. This implied that more plant population produced more plants per unit area provided the seeds have similar viability. Furthermore, the number of seeds sown increased with increasing seed rates hence the increase in plant population. These results also agreed with the findings of Ayub et al. (2002) and Ayub et al. (2007). The Dry Matter content increased with increase in plant population. As plant population increased from 53,333 - 421,072 plants/ha, DM content varied from $23.64 \%-27.22 \%$ which is within the range of $12.6-47.6 \%$ for maize fodder as cited by Heuze (2016). Hunter (1986) also reported that at early stage of maturity, DM contents with a range of $24-30 \%$ of maize forage might be considered a good quality. The differences in reported DM content are based on hybrids, harvest stage and agronomic factors (Russell et al., 1992). The Crude Protein increased with increase in plant population with $\mathrm{P} 3$ and $\mathrm{P} 4$ having high $\mathrm{CP}$ mean values which was in line with Lewis et al. (2004) who reported a similar range in CP for higher densities. This shows that higher quality of leaves could be obtained with higher plant population harvested at a much earlier age, as the age of the harvest influences the nutrient composition of forages (Norton, 1994). Cusicanqui and Lauer (1999), reported a significant increase in CP content at higher plant densities. Muller et al. (2005) also found that increase in seed density increased the $\mathrm{CP}$ content but reduced the contents of Neutral and Acid Detergent Fiber and Lignin and this was observed as the NDF, ADF and ADL decreased with increase in plant population. Plant population showed significant differences $(\mathrm{P}<0.05)$ in NDF, $\mathrm{ADF}$ and ADL concentrations, which is consistent with the findings of other researchers (Graybill et al., 1991, Cox et al., 1994, Cusicanqui and Lauer, 1999). According to Blezinger (1999), an ADF content of below $31 \%$ is considered as prime quality, $31 \%$ - $35 \%$ as very good quality, 36\% - 40\% good quality, $41 \%$ - $42 \%$ medium quality, $43 \%$ - $45 \%$ low quality and above $45 \%$ very low quality. Likewise, Graybill et al. (1991) also reported that little difference was noted among plant density for ADF and NDF content. The reduction in fibre components may be attributed to the decline trend in the stem diameter of maize fodder at higher plant population. The Coefficient of Preference (in ratio) and Percentage Preference (in \%) of individual forage which measures preference for forages by ruminants shown in Table 4 did not show any variability in preference. This could be related to the previous experience of the animals or the relative importance of changing dietary preference of ruminants as reported by Ikhimoya and Imasuen (2007) that ruminants readily accept forages with which they have had previous experience while Provenza and Cincotta (1994) 
reported that pre-conditioning of ruminants to a particular forage influence their choice among a variety of forages. The Dry Matter Digestibility across the treatment was relatively high and this is in agreement with Azim (2000) and Kim et al. (2001) that DMD of fodder is high at vegetative stage and low at maturity. The DMD value with the same row spacing increased with increase in seed rate in plant population, this is in agreement with Joshi and Kumar (2007) that increase in seed rate increased the DMD in fodder maize.

\section{Conclusion}

From this study, for maximum agronomic efficiency and increase in plant population resulting in increased forage yield, an increase in plant density should be considered. It was observed that an increase in plant density produced more forage yield of very good quality which was of high digestibility and readily preferred by the animal.

\section{References}

Amanullah, R., Khattak, A. and Khalil, S. K. 2009. Effects of plant density and Nitrogen on phonology and yield of maize. J. Plant Nutr. 32: 246-260.

AOAC, 2005. Official methods of analysis, 18 th edition. Wash ington, DC, USA : Association of $O$ f $f$ i c i a $l$ Analytical Chemists.

Ayub, M., Mahmood, R., Tanveer, A. and Sharar, M. S. 1999. Effect of seeding density on fodder yield and quality of two maize varieties. Pakistan Journal Biological Sciences, 2(3): 664-666.

Ayub, M., Nadeem, M., Tanveer, A. and Hussain, A. 2002. Effect of different levels of nitrogen, seed rate and harvesting time on the growth, yield and quality of sorghum fodder. Asian Journal of Plant Science, 1 (4): 304-307.

Ayub, M., Nadeem, M. A., Tanveer, A., Tahir, M. and Khan, R. M. A. 2007. Interactive effect of different nitrogen levels and seeding rates on fodder yield and quality of pearl millet. Pakistan Journal of Agricultural Sciences, 40 (4): 3933.

Azim,A., Khan,A. G., Nadeem M.A. and Muhammad, D. 2000. Influence

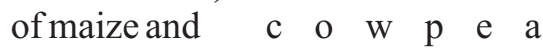
intercropping on fodder production and characteristics of silage. Asian A.J.Sci., 3: $\quad 781-784$.

Babayemi, O. J. 2007. In vitro fermentation characteristics and acceptability by West African dwarf goats of some dry season forages. African Journal of Biotechnology. 6(10):1260-1265.

Babayemi, O. J., Ajayi, F. T., Taiwo, A. A., Bamikole, M. A. and Fajimi, A. K.2006. Performance of West African dwarf goats fed Panicum maximum and c o n c e n t r a t e d i e t s supplemented with Lablab (Lablab purpureus), Leucaena (Leucaena leucocephala) and Gliricidia (Gliricidia sepium) foliage. Nigerian Journal of Animal Production 33(1): $102-111$.

Blezinger, S. B 1999. Developing sound forage analyses a program. http://www.cattletoday.com/ archive/1999/September/Cattle_T oday20.shtml

Brewbaker, J. L., 2003. Corn production in the Tropics: the Hawaii experience. Univ. Hawaii, Coll. Tropic. Agric. Hum. Resources.

Cox W. J., Cherney J. H., Cherney D. J. R., and Pardee W. D. 1994. Forage 
quality and harvest index of corn hybrids under different growing conditions. Agron. J., 86: 277-282.

Cox, W. J. 1996. Whole-plant physiological and yield responses of maize to plant density. Agron. J. 88: 489-496.

Cox, W. J., Cherney, D. R. and Hanchar, J. J. 1998. Row spacing, hybrid, and plant density effects on corn silage yield and quality. J. Prod. Agric. 11: 128-134.

Cusicanqui, J. A. and Lauer, J. G. 1999. Plant Density and Hybrid Influence on Corn Forage Yield and Quality. Agronomy Journal, 91(12): 911915.

EARO (Ethiopian Agricultural Research Organization), 2004. Directory of released crop varieties \& their recommended cultural practices. Addis Ababa, Ethiopia.

Graybill J. S., Cox W. J. and Otis D. J. 1991. Yield and quality of forage maize as influenced by hybrid, planting date, and plant density. Agron.J., 83: 559-564.

Halima, H. and Chauhan, S. S. 2003. Effect of rate of maize leaf defoliation at various growth stage on grain, Stover yield components of maize and under sown forage production. Indian Journal of Agricultural Research $\mathrm{v}$. 32, n.2, p. 35.

Hassanzadeh, M. H. and Basafa, J. 2006. Effect of planting method and plant population on seed and forage yield of maize in saline condition. Agricultural and Resources Research Centre

o f Khorasan, Razavi.

Hunter R. B. 1986. Selection hybrids for silage maize production: A Canadian experience. In: Dolstra O., Miedema P. (eds.): Breeding of silage maize. In: Proc. $13^{\text {th }}$ Congr. Maize and Sorghum Section of EUCARPIA, Wageningen. PUDOC, Wageningen: 140-146.

Heuzé, V. and Tran, G. 2016. Maize grain. Feedipedia, a programme by INRA, CIRAD, AFZ and FAO. http://www.feedipedia.org/node/5 56.

Ikhimioya, I. and Imasuen, J. A. 2007. Blood profile of West African DwarfGoats Fed Panicum maximum supplemented with Afzelia Africana and New bouldia laevis. Pakistan Journal of Nutrition 6(1): 79-84.

Joshi, Y. P. and Kumar, K. 2007. Response of forage maize (Zea mays L.) to the levels of nitrogen and seed rates. Forage Research, 33(3): 171-173.

Kim, J. D., Kwon, C. H. and Kim, D. A. 2001. Yield and quality of silage corn as affected by hybrid maturity, planting date and harvest stage. Asian Aust. J. Anim. Sci., 14: 1705-1711.

Lewis A. L., Cox W. J. and Cherney J. H. 2004. Hybrid, maturity, and cutting height interactions on $\mathrm{c}$ o $\mathrm{r} \mathrm{n}$ forage yield and quality. Agron. J., 96: 267-274.

Malik, M. A., Hussain, M. and Awan, S. I. 2007. Yield response of fodder sorghum (Sorghum bicolor) to seed rate and row spacing under rain-fed conditions. Journal of Agricultural and Social Sciences, 3 (3): 95-97.

Mazaheri, D., Askarirad, M. and Bankesaz, A. 2002. Effect of planting method and plant density on yield and yield components of two fodder maize hybrids. $7 \mathrm{th}$ agronomy $\begin{array}{llllllllllll}\mathrm{s} & \mathrm{y} & \mathrm{m} & \mathrm{p} & \mathrm{o} & \mathrm{s} & \mathrm{i} & \mathrm{u} & \mathrm{m} & \text {. }\end{array}$ https://www.researchgate.net/publ 
ication/260845486.

Methu, J. N., Kiruiro, E. M. and Abate, A. N. 2006. Your feed shortage problem: Use maize forage. KARI resource center, Nairobi.

Muller, L., Manfron, P. A., Santos, O. S., Medeiros, S. L., Haut, P., Dourado, V., Neto, D., Fagan, E. and Bandeira, B. 2005. Growth and bromatologic composition of hydroponic maize fodder at different dates of harvest and sowing densities. Zootecnia Tropical, 23 (2): 105-119.

Norton, B. W. 1994. Tree legumes as dietary supplements for ruminants. In Gutterridge, R.C.; Shelton, H.M. (Eds). Forage legume in tropical Agriculture. Cambridge. U.K: CAB International University Press, p.193-202.

Norwood, C. A. 2001. Dryland corn in western Kansas: Effect of hybrid maturity, planting date and plant population. Agron. J., 93: 540-547.

Olorunnisomo, O. A. 2011. Silage characteristics and acceptability of elephant grass and c a s s a va peel silage by ruminants in southwest Nigeria. In: Proceedings, $3 \mathrm{rd} I n t e r n$ a t $i$ o $n$ a l Conferenceon Sustainable Animal Agriculture for Developing Countries (SAADC 2011), Volume III, 26 - 29 July, 2011, Nakhon Ratchasima, Thailand, pp 201-206.

Olorunnisomo, O. A. and Fayomi, O. H. 2012. Quality and preference of zebu heifers for $1 \mathrm{e} \mathrm{g} \mathrm{u} \mathrm{m} \mathrm{e} \mathrm{o} \mathrm{r}$ elephant grass-silages with cassava peel. Livestock Research for Rural Development Volume 24 Article $\begin{array}{lllll}\text { \# } & 1 & 6 & 8\end{array}$. http://www.lrrd.org/lrrd24/9/olor2 4168.htm.

Osman, S., Abdelsalam, Y. and Abdelsalam, K. 2010. Effect of nitrogen and seed rate on $\mathrm{g} r \mathrm{ow} t \mathrm{~h}$ and yield of forage sorghum [Sorghum bicolor (L.) Moench]. SudanJ.Sci. Technol., 11: 123135.

Provenza, F. D. and Cincotta, R. P. 1994. Foraging as self- organizational 1 e a r n i g p r o c e s s : Accepting adaptability at the expense of predictability. In: Hughes R. N. (editor) Diet selection. Blackwell Scientific Publications, Oxford, UK pp 79 101.

Russell, J. R., Irlbeck, N. A., Hallauer, A. R. and Buxton, D. R. 1992. Nutritive value and ensiling characteristics of maize herbage as influenced by agronomic factors. Anim. Feed Sci. Technol., 38: 11-24.

SAS, 1999. Statistical Analysis System SAS, User Guide, SAS/STAT Version $6{ }^{\text {th }}$ Edition, $S$ A S Institute, Inc. Raleigh New Cary, NC, U.S.A. pp 346-350.

Singh, R. P., Kumar, Ranjit and Singh, N. P. 2002. Transitioning maize seed industry in India: Sectoral dimensions. Indian Journal of Agricultural Economics, 57 (3): 430-442.

Van Soest, P. J., Robertson, J. B. and Lewis, B. A. 1991. Methods for dietary fiber, neutral detergent fiber, and non-starch polysaccharides in relation to animal nutrition. J. Dairy Sci., 74, 3583-3597.

Received: $10^{\text {th }}$ August, 2019 Accepted: $19^{\text {th }}$ December, 2019 